\title{
Legal Status of the European Space Agency
}

\section{Renáta Dolanská}

Doctor of Law, Greek-Catholic Theological Faculty of the University of Presov

(Presov, Slovakia)

E-mail: partners@dolanska.sk

\section{Vira Halunko}

Doctor of Law, Professor, Kherson Faculty Odessa State University of Internal Affairs

(Kherson, Ukraine)

E-mail: vera.galunko.00@i.ua

https://orcid.org/0000-0002-0563-0576

\begin{abstract}
In the article, the authors reveal that, in accordance with the current international and national legislation of member states, the positive legal status of the European Space Agency (ESA) has been established. The authors emphasize that some factors make the legal status of ESA unprecedented, due to the concept of inviolability of premises, property and correspondence; exemption from all types of taxes, duties and other financial burdens. ESA staff and experts have the same rights as employees of diplomatic institutions. The authors argue that this potential remain unutilized because European private companies and their employees are exempt from it. The article proposes ways to improve the legal status of ESA.

Keywords: Europe, European Space Agency, institution of inviolability, Space, legal status, private space companies
\end{abstract}

Received: December 26, 2018; accepted: February 17, 2019

Advanced Space Law, Volume 3, 2019: 5-17.

https://doi.org/10.29202/asl/2019/3/1

\section{Introduction}

The improvement of the European Space Agency (ESA) legal status is a central issue, since after the adoption of the 1975 Convention for the establishment of a European Space Agency, social relations in outer space have changed. This is due not only to the development of new space technologies, but also and mainly to private companies' access to outer space. The State monopoly on the exploration and use of outer space has expired.

In the specialized legal literature on space law, the issue of commercialization of the use of outer space is often analysed. However, the immediate cause of the difficult times for ESA,

(C) Dolanská, Renáta, 2019.

(C) Halunko, Vira, 2019. 
because of the outflow of commercial orders to foreign private space companies, was not associated with the problems of the ESA outdated legal status.

Space is a strategic asset of humankind and in particular of Europe. It is an indispensable tool of European science that provides basic knowledge of weather, gravity, magnetism and other natural and artificial aspects that directly or indirectly affect the lives of people on Earth. Space is not only a public good. In the course of the exploration of outer space, humanitarian values occur and develop as well. In sharing space, European nations and peoples strengthen their European identity and smooth the problems that the European Community now faces. The sharing of space has become a source of new services that contribute to improving the social situation of citizens and economic development of all European States.

Therefore, competitiveness of the European space industry increases and subjects of public space activities develop. In addition, the use of space contributes to the growth of living standards for all European citizens.

The European Space Agency, which promotes the development of space technology for the benefit of the peaceful exploration and use of outer space, plays a leading role in the public administration of space activities.

The European Space Agency is a worldwide recognized brand. Its name is protected as an EU trademark in all classes of products and services related to space activities. ESA officially presents itself as the European Community gateway for the exploration and use of outer space. It is an international space research organization dedicated to space exploration. ESA's mission is to develop the capabilities of a united Europe, so that through European space investment, European citizens get practical benefits [Budget ESA, 2019]. It should be emphasized that ESA is not part of the structure of the European Union. ESA members such as Switzerland and Norway are not EU members, while not all member countries belong to this authoritative international partnership. Currently, 22 states are members of ESA and their number is constantly growing. The ESA headquarters are in Paris [Budget ESA, 2019].

An important factor in ESA successful performance is the joint, with a French Space Agency, usage (2/3 of total funding) of Center Spatial Guyanais in French Guiana, located just 580 kilometres from the equator [Guiana, 2019].

During the 1990s and two decades of the twentieth century, ESA became a market leader in commercial launches, and in recent years has also proven itself as the main actor in the exploration and use of space. Following the signing of the Convention for the establishment of a European Space Agency (30.05.1975) and its entry into force (10.10.1980), this international European society has passed a glorious way. Under ESA auspices, a large number of scientific studies were carried out that making a significant practical effect, both for the public administration of European States and for private individuals and businesses. The ESA budget for 2019 is $€ 5.72$ billion, filled by all member States in proportion to the total national budgets [Budget ESA, 2019]. Depending on the amount of contributions, industrial contracts are distributed to the space companies of member countries. That is, through industrial contracts for space programs, ESA invests in each Member State, the amount equivalent to the contribution of each Member State. That enables even countries with a small overall budget to participate in space projects.

ESA successes are the development and effective operation of the full range of Ariane rocket carriers (from light to the heaviest rockets), which can place any spacecraft into orbit and into outer space. Automated transfer vehicles, ATV, developed by ESA, are successfully used. From 2005 to 2015, Venus Express spacecraft, VEX, has carried out a large number of 
successful studies in orbit of Venus, in particular the study of the atmosphere of this planet interacting with solar wind.

The Gaia Space Telescope, launched in orbit on December 19, 2013, works successfully to form a detailed map of the stars of our Galaxy, the Milky Way [The Gaia mission, 2016].

Therefore, ESA is a leading global entity in the exploration and use of outer space, the performance of which is based on the Convention for the establishment of a European Space Agency that requires to be amended and supplemented.

The ESA leadership is also aware of this. The ESA Council, Space19+, will be held in Spain (Seville, 27-28 November 2019), at the level of Ministers of the Member States, in order to work out new areas and improve the efficiency of existing space exploration studies. It is to decide on funding their programs for the next few years. This year, transition from Ariane 5 and Vega launchers to the next-generation rockets, Ariane 6 and Vega C, will occur [Gannon, 2019]. That is a very important factor, because both ESA and Arianespace, the first European commercial launch company, compete with SpaceX, the American private company.

Therefore, ESA has both outstanding successes in the exploration and use of outer space and shortcomings. The authors argue that the main is the absence of significant results in improving EU citizens' lives from its activities. According to sociological research, no more than 40 percent of the respondents know exactly about the existence of the Agency. This is despite the fact that ESA funding averages 10 euro per year per citizen. [Gannon, 2019].

Consequently, for various reasons and primarily due to lack of funding, space projects such as the Darwin project for the launch of the system of infrared telescopes for direct observation of exoplanets and the search for life on them, Hermes, a multiple spacecraft, remained the project on Earth. These factors, as well as the dynamic development of private space companies in the United States, require a new look at the legal status of the European Space Agency, in particular regarding the involvement of private companies in the use of outer space.

Therefore, in order to increase ESA efficiency, it is necessary to increase significantly the rights of private space companies of member countries. For this purpose, Member States should adopt legislation that would empower private companies to develop and launch space technology and, consequently, to generate profits. In this area, the principles and legal instruments of private international space law should be developed [Halunko \& Didenko, 2019].

In order to increase the involvement of private investment, the effective use of the ESA budget, the European Community should achieve the legal status for private space companies registered in the member countries that provides them with the distribution of inviolability elements the same as ESA units enjoy. In addition, certain employees of private space companies should enjoy the immunity, the same as recorded to the experts of the Agency.

ESA should shift from the direct exploration and use of outer space to functions promoting the development of European space public and private law, planning, providing support, including the inviolability of private space companies and their employees, the admission of all private space companies to their launch sites on a commercial basis, conducting competitive tendering and arbitration. These activities should empower ESA to oppose dozens of successful private companies in Europe to several successful companies in the US.

Therefore, in the article, the authors have objectives to disclose a set of legal elements that form the content of the legal status of ESA, such as the grounds for the occurrence and scope of legal personality, the aim and functions, legal obligations and relevant legal rights, the concept of privilege and immunities, as well as procedures for settling legal disputes. All these issues 
are revealed from the perspective of the commercialization of the use of outer space by private space companies of Member States. Nowadays, legal issues exist; private space companies that participate in projects cannot use the privileges that have ESA units. The authors argue why it is necessary to distribute privileges to private space companies of member countries that take part in ESA projects.

\section{The content of the legal status of the European space agency}

Legal relations are always relations between people who enter into them to ensure their rights, freedoms or public interest. In turn, legal relations are social relations. Legal relations that determine the legal status of the European Space Agency are not an exception to this rule. According to Encyclopaedia Britannica, social status is the relative rank that an individual holds with attendant rights, duties and lifestyle, in a social hierarchy based on honour or prestige [Encyclopaedia, 2019]. From the legal perspective, the status is the collection of rules defined by the law, which are imposed by authority for a certain category of individuals [Legal status, 2019]. In the special legal literature, the legal status of a person is understood broadly as the totality of subjective rights and legal obligations, in combination with the scale and capacity of legal personality and legal responsibility.

The authors advocate this approach as most appropriate to determine the content of the legal status of the European Space Agency in this study. It can be used as a basis. Evidently, the specifics of the issues studied should be taken into account. The Convention for the establishment of a European Space Agency provides for a legitimate understanding of the legal status of the European Space Agency: ESA has legal personality, its staff members and experts, as well as and the representatives of the Member States enjoy privileges and immunities [Convention, 1975].

In other words, in the international legal act under analysis, the focus is on the privileges and immunities, which are granted to ESA as a subject of international law with a special status. Actually, it can be argued that the level of legal protection of ESA, its units and staff members is unprecedented and consistent with diplomatic standards.

The authors argue that the content of the legal status of the European Space Agency is a set of: a) grounds for the occurrence and scope of legal personality; b) purpose and functions (missions); c) legal obligations; d) legal rights; e) the privileges and immunities of staff members and independent experts; h) procedures for settling legal disputes [Convention, 1975]. Therefore, the content of the legal status of the European Space Agency is a set of legal elements: legal personality; purpose and functions; legal obligations and legal rights; privileges and immunities of the Agency's staff; and factors in the settlement of legal disputes.

\section{European space agency membership and key programmes}

ESA is an international organization, which consists of 22 Member States and the number of which is constantly growing. Since the signing, no country has left ESA that involves its new members constantly. Member States coordinate financial and intellectual resources for joint planning and implementing space activities. Nowadays, ESA Member States are Austria, Belgium, Czech Republic, Denmark, Estonia, Finland, France, Germany, Greece, Hungary, Ireland, Italy, Luxembourg, the Netherlands, Norway, Poland, Portugal, Romania, Spain, Sweden, Switzerland and the United Kingdom. Slovenia is an associate member. Canada takes 
part in some projects under a cooperation agreement. Bulgaria, Croatia, Cyprus, Malta, Latvia, Lithuania and Slovakia have cooperation agreements [New, 2019].

For almost 40 years, Member States have been investing in space programs through ESA and have got many remarkable achievements. This success has raised the interest of European countries that are not yet members of this space club in the joint exploration and use of outer space.

In the present context, ESA performs a number of operational and scientific missions in cooperation with national space administrations, in particular Japanese JAXA, French CNES, Italian Agenzia Spaziale Italiana, German DLR, American NASA and Chinese CNSA. Within the framework of a public-private partnership, European satellite operators belong to ESA's significant partners.

The ESA main scientific program is Cosmic Vision 2015-2025, which is the current cycle of long-term planning of space science missions. It provides the stability needed for space industry activities for decades. This will enable to go from theoretical developments of initial concept to the production of scientific results. It provides with new more affordable and highquality space services to the general public through newly developed space technologies [Cosmic Vision, 2019].

Moreover, ESA participates actively, on a competitive basis, in the implementation of Discovery and New Frontiers, NASA's space programs; implements successfully Horizon 2020, the program for 2014-2020, which is the largest EU research and innovation programme with nearly $€ 80$ billion of funding and with the attraction of private investment. Horizon 2020 has the political backing of Europe's leaders and the Members of the European Parliament. It is a means to drive economic growth and create jobs. It is an investment in the EU future in connection with sustainable and inclusive growth and jobs. The goal of Horizon 2020 is to ensure high quality production in the EU Member Countries based on the space technology development. It removes barriers to space innovation implementation in production and existing social sector [What is Horizon, 2014].

\section{The purpose and functions (missions) of European space agency}

The purpose of ESA is to provide the exploration and use of space for peaceful purposes by European States with a view to their being used for scientific purposes and the operational system of common space activities [Convention, 1975].

ESA achieves this goal by elaborating and implementing a long-term European space policy; розробки, організації прийняття та виконання by elaborating, organizing the adoption and implementation of the European space programme [ESA, 2019]; by cooperating with national and international organisations and institutions; by elaborating and implementing activities and programmes in the space field; by coordinating the European space programme and national programmes of Member States; by elaborating and implementing the European industrial policy and by adjusting to Member States' policy; by increasing the overall efficiency of European States' space potential by combining and better utilizing space-related resources [Convention, 1975].

Nowadays, while most of the spacefaring States at the legislative level by State licensing have empowered private companies to develop and launch rocket carriers and artificial satellites, ESA's involvement of private companies of Member States and other spacefaring States should be a significant function. This should be a significant function of ESA [What is ESA, 2019]. 
Therefore, a new key function of ESA should be the involvement of private investment and private space companies of ESA Member States to projects, which requires appropriate changes and additions to its legal status.

\section{European space agency public administrations}

In ESA, around 2,200 employees from all the Member States work. These are scientists, engineers, information technology and administrative staff. These individuals are in employment relationship with ESA.

Public administration of ESA is carried out by collective (ESA Council, assisted by the Bureau of the Agency Council) and individual (Director General and staff members) subjects. Aside, experts, who are not directly the members of ESA, but perform certain functions, have specific administrative rights and responsibilities, should be distinguished.

The ESA Council consists of representatives from all Member States and holds meetings, if necessary, at the level of delegates or ministers. Meetings are held at the headquarters unless the Council decides otherwise. The Council provides the basic space policy guidelines, develops the European space programme. Each member state represented on the Council has one vote, regardless of its financial contribution to the ESA budget.

According to unanimous decisions of the Council, ESA may cooperate with international organizations and institutions, as well as with governments and public organizations and institutions of non-member States. A non-member State has the right to vote in the Council when matters related solely to the programme, in which that State participates, are under consideration. Such cooperation may also take the form of the relevant associate membership.

Every two years, the Council elects the chair and vice-chairs, who may be re-elected once in the following year. The chair manages the work of the Council and ensures the preparation of its decisions.

The chair of the Council is in charge of: informing the Member States about proposals for the implementation of programmes; ensuring coordination of ESA bodies; establishing working relationships with the Member States through their delegates; advising the Director General and receiving all necessary information from him/her.

The chair of ESA is assisted by the Bureau, membership of which is approved by the Council. The Director General is elected by the Council by a two-thirds majority of all Member States, similarly his/her mandate is terminated. The Director General is the chief executive officer of ESA and its legal representative. He/she participates in all activities necessary for the public and international management of ESA, the implementation of its programmes, policy and objectives in accordance with the directives issued by its Council. He/she may attend meetings of the Council without the right to vote. The Director General is assisted by scientific, technical, administrative and clerical staff. Senior management is appointed by the Council on the recommendation of the Director General. Other employees are appointed and may be dismissed by the Director General.

Scientists, who are non-staff members, but conduct research in ESA institutions, are subordinated to the Director-General and are required to adhere to the general rules adopted by the Council [Convention, 1975].

ESA has its parts in the Member States, namely: the European Astronauts Centre in Germany; the European Space Astronomy Centre (Spain); the European Space Operations Centre (Germany), the Centre for Earth Observation (Italy), the European Space Research 
and Technology Centre (Netherlands), the European Centre for Space Applications and Telecommunications (U.K.), the European Space Security and Education Centre (Belgium), as well as liaison offices in Belgium, USA and Russia. ESA's main object is a launch base in French Guiana and ground/tracking stations in various parts of the world.

Therefore, ESA's public administration bodies should include, with an advisory voice for now, representatives of European private space companies and public organizations that deal with the issues of the use of outer space, in particular space debris.

\section{Modern trends in the public administration of implementing European space agency industrial policy}

In the ESA internal organizational system, legal and organizational activities of industrial policy implementation are under focus. They are aimed at making the most of ESA funds, achieving the best results of research implementation in practice for the benefit of citizens and business of Member States.

Existing international and domestic regulations enable to conclude about certain trends in public administration of the implementation of ESA industrial policy. The policy is carried out with the aim of: the efficient use of the industrial potential of the Agency's production structure; coordination of national industrial policies of the Member States; control over the compliance of all space companies with the standards and industrial policy of the Agency. The industrial policy of ESA is focused on structuring the industrial potential, developing the unification and specialization of all parts.

Industrial policy is carried out by establishing a relationship between production capacities and potential markets for space products and space services; signing of contracts with industrial space companies of all member countries and ensuring interaction with other subjects of industrial policy of other international bodies and organizations related to space subjects.

Moreover, the authors highlight measures for preventing violations of the rights of partners, in the execution of contracts with space industrial entities that are not part of ESA. In order to achieve this, the Member States should monitor that multilateral space projects that they implement with non-member States of ESA do not jeopardize the scientific, economic or industrial goals of ESA.

Another factor in the public administration of industrial policy is the obligation of each ESA Member State to make available for participation by space companies of other Member States all new projects that they intend to carry out in collaboration with ESA, or even alone. This approach ensures the involvement of space companies from all Member States without exception.

From the administrative perspective, the procedure is as follows, the ESA Member State, which intends to undertake any project, notifies the ESA Director General of it. The notice, in particular, indicates the content and timing of the project, which makes it possible for other Member States to inform their space companies in advance about the proposal and receive applications from them for the performance of certain works or services. Moreover, the initiating Member State should use its best endeavours to accommodate all reasonable responses of other Member States that wish to participate in a space project. Only after the coordination of all the specific aspects from other Member States, the initiating State submits a formal proposal to ESA with a detailed specification of the role of each State in this project [ESA, 1975]. 
In general, the authors agree with a reasonable approach to the planning of public administration of the implementation of space projects by the Member States based on a solidarity. However, it should be noted that the exclusion of private companies, which in most cases execute directly space orders, from this process that adversely affects the Agency's competitiveness in face of, for example, NASA, which widely uses private companies to implement their programmes, including SpaceX. Therefore, the public administration of the implementation of industrial policy and the organization of collaboration in ESA between the Member States is perfect. However, it should be noted that private space companies of the Member States and public organizations that deal with the use of outer space are directly excluded from this process. This leads to constant inadequacies in space projects and the inefficient use of ESA funds, which has resulted in some lagging behind NASA, which widely uses private companies to implement their programmes.

\section{Legal rights and obligations of European space agency}

On the date when the Convention enters into force, ESA has assumed all rights and obligations regarding the international legal and public legal framework of the exploration and use of outer space with the involvement of the Member States. ESA is fully responsible for space activities of the European continent, in particular for the joint organization, preparation and launch of space objects. Generally, after the entry into force of the Convention, ESA takes over all legal rights and legal obligations permanently. The results of research published by the Agency shall be its property [Convention, 1975]. In addition, it has the right to collect relevant information and share it with the Member States, pay attention to gaps, duplication, provide advice and assistance for the harmonization of international and national programmes.

With respect to the coordination and integration of programmes, the Agency has the right to receive in good time from the Member States information on projects relating to new space programmes; undertake evaluation of scientific and industrial programmes; formulate appropriate rules to be adopted by the Council by a unanimous vote of all Member States.

In addition, the Agency has other rights:

- to conclude contracts, to purchase and dispose of movable and immovable property, as well as to participate in litigation;

- to create any funds, to receive cash and securities and to freely dispose of them;

- to have no less rights and legal opportunities than those granted by each Member State to other international organizations [Convention, 1975].

ESA legal duties include mandatory and optional activities. The mandatory activities are:

a) ensuring the elaboration and implementation of scientific programmes, including programmes for the exploration and use of the Earth by satellites and other space systems; maintaining liaison with users of space technology and informing them about its regulatory and administrative acts;

b) ensuring the execution of activities, such as education, documentation, studies of future projects of scientific space research.

The optional activities include ensuring the execution of programmes regarding: the design, development, construction, launching, placing in orbit, and control of satellites and other space systems; the design, development, construction, and operation of launch facilities and space transport systems. 
In addition, it should be noted that with respect to commercial activities ESA is obliged to:

- meet the requirements of the European space programme and the coordinated national space programmes in a cost-effective manner;

- improve the world-wide competitiveness of European industry by maintaining and developing space technology and by encouraging the rationalisation and development of an industrial structure appropriate to market requirements making use in the first place of the existing industrial potential of all Member States;

- ensure that all Member States participate in an equitable manner in financing commercial programmes.

Therefore, ESA has well-balanced legal rights and obligations that, provided they are effectively used to involve European private companies to their programmes, can ensure the dynamic development of advanced technologies in favour of all citizens of Europe.

\section{Inviolability of European space agency}

The Agency has immunity from jurisdiction and execution. Moreover, the buildings and premises, documentation, archives of the Agency are inviolable. The Agency's property and assets, wherever situated, is immune from requisition, confiscation, and expropriation. Within the scope of its official activities, the Agency's property and income is exempt from direct taxes. Goods imported or exported by the Agency or on its behalf are exempt from all import and export duties and taxes and from all import or export prohibitions and restrictions. The circulation of publications and other information material cannot be restricted by Member States either in legal or administrative manner. No censorship can be applied to official communications of the Agency. Member States should take all appropriate measures to ensure the inviolability of the Agency and ensure non-violation of the related rights by other public or private persons [Convention, 1975].

Therefore, ESA has extraordinary provisions regarding the inviolability of premises, property, correspondence, exemption from all types of taxes, duties and other fiscal burdens.

\section{Privileges and immunities of European space agency's staff}

The representatives of the Member States have undertaken and adhere to the following privileges and immunities with regard to the Agency's staff:

- immunity from arrest and detention, and from seizure of their personal luggage;

- immunity from jurisdiction, even after the termination of their mission, in respect of acts, including words spoken and written, done by them in the exercise of their functions;

- inviolability for all their official documents;

- exemption from all obligations in respect of military service;

- the right to use codes and to receive documents or correspondence by special courier or sealed bag;

- exemption for themselves and their spouses from all measures restricting entry into other State.

However, it should be noted that privileges and immunities are accorded to representatives of Agency, not for their personal advantage, but in order to ensure complete independence in the exercise of international, public, business and other functions of ESA. In addition, the immunity does not apply to the Agency's staff that have violated the road safety regime. 
Experts other than the staff members, but in carrying out its missions, in the exercise of their functions, enjoy the same privileges and immunities as the Agency's staff, such as: immunity from jurisdiction in respect of acts, including words written and spoken, done by them in the exercise of their functions; inviolability for all their official papers and documents. They enjoy the same facilities as regards monetary and exchange regulations and as regards their personal luggage as are accorded to the officials of foreign governments on temporary official missions [Convention, 1975].

Therefore, ESA staff members enjoy unprecedented legally reasonable privileges the same as are accorded to employees with diplomatic status for performing the functions of the Agency.

\section{Settlement of disputes in European space agency}

In any social system, there are conflicts to be resolved, including in a legal way. The social relations that arise in a complex ESA system are no exception to this rule.

Any dispute between two or more Member States, or between other subjects, which is not settled by or through the Council of the Agency, at the request of any party to the dispute, is submitted to arbitration of the Agency.

The Arbitration Tribunal consists of three members. Each party to the dispute nominates one arbitrator; the first two arbitrators shall nominate the third arbitrator, who is the chairman of the Arbitration Tribunal. Member States or the Agency, not being parties to the dispute, may intervene in the proceedings if they consider that they have a substantial interest in the decision of the case.

The Arbitration Tribunal determines its seat and establish its own rules of procedure. The award of the Arbitration Tribunal is made by a majority of its members, who may not abstain from voting. This award is final and binding on all parties to the dispute and no appeal shall lie against it. The parties comply with the award without delay. In the event of a dispute as to its meaning or scope, the Arbitration Tribunal shall interpret it.

Non-fulfilment of obligations under the award of the Arbitration Tribunal by any Member State may entail a sanction in the form of cessation of a membership of the Agency. This decision is legal in the event of being taken by a two-thirds majority of all Member States. [Convention, 1975].

Therefore, within ESA, a specific system of compulsory settlement of legal disputes is based on the involvement of both representatives of the parties to the dispute as arbitrators and an independent judge agreed by the parties. The authors argue that the sanction for failing to comply with the award of ESA Arbitral Tribunal is successful. If a Member State fails to comply with the award of ESA Arbitration Tribunal, it ceases to be a member of the Agency forcibly. The authors argue that this rule should be applied to private companies involved in the implementation of the Agency's programmes.

\section{Further improvement of the activities and legal status of European space agency}

Nowadays, the Agency is going through hard times. This is due to a long-term development in the absence of competition. With the United States' involvement of private companies in the implementation of space programs, it has become clear that the efficiency of the use of ESA funds should be increased. Furthermore, the legal status of the Agency needs to be improved. 
The basis for improving the legal status of ESA is certain vectors of promising activities. They can be divided into activities allowing for development of new activities and programmes in the short and medium term, as well as others aimed at the future.

Planning in the long term is the Advanced Concepts development. These Concepts are determined channels for the study of technologies and ideas that are of strategic importance in the long term planning. Some of the leading topics investigated include innovative materials, artificial intelligence, bio-engineering, computational science, earth system science, energy systems, fundamental physics and informatics.

Ministers of ESA Member States have decided on missions of ESA, such as practical implementation of scientific innovation and job creation. They have determined that the efficiency of the space sector should be maximised in favour of citizens and businesses of all member countries/

One of the prospecting missions is an ESA project for extraction of minerals from asteroids. A Swedish-Finnish-German-Czech consortium designs APEX CubeSat (miniature APEX spacecraft) for ESA to test the possibility of extraction of minerals from asteroids. It will operate as a mineral prospector of availability and chemical composition of minerals on asteroids, and prepare the way for mining missions [Hera's, 2019].

Possible U.K. Brexit from the European Union puts significant challenges to ESA, requiring the establishment of a renewed legal status for the U.K. as a non-EU country member of ESA. In this case, the legal precedents of the ESA relationship with non-EU countries, such as Switzerland and Norway, should be used. It should be considered that the U.K. has a positive development of legislation that can increase the involvement of private companies in space activities, including the construction of private launch sites [Hughes, 2018; Smith \& Leishman, 2019].

ESA continues classic activities, for example, in 2019, an Italian astronaut, Luca Parmitano, is scheduled to fly to the International Space Station. Moreover, ESA should raise its public image. For example, only 37 percent of Europeans knew exactly what ESA was, and they vastly overestimated how much space activities cost taxpayers. The actual amount for ESA maintenance is about 10 euros per year per citizen in the countries polled, which were Germany, France, Italy, the U.K., and Spain [Gannon, 2019].

\section{Conclusions}

Therefore, the authors of the article prove that, in accordance with international and national legislation, the legal status of ESA has the potential to effectively use financial contributions from Member States. According to some factors, the legal status of the Agency is unprecedented in terms of international law, for example, the concept of inviolability of premises, property and correspondence of the Agency, exemption from all types of taxes, duties and other financial burdens. In addition, ESA staff and experts enjoy the same rights as are accorded to employees of diplomatic institutions.

However, the high legal status provided for by legal regulations remain unutilized for some extent. This due to exemption of private companies from its provisions. Ignoring this challenge, ESA will gradually turn into a non-competitive international institution.

Therefore, in order to increase efficiency, ESA should significantly increase the rights of private space companies of Member States. It is necessary to lobby the Member States to adopt legislation that would not only allow private companies to develop and launch 
space technology, but also would bring significant profits to private space companies. In this area, the foundations and legal instruments of private international space law should be developed.

The authors argue that some elements of the high legal status of ESA units should involve private space companies registered in Member States and executing contracts with ESA. Moreover, the leaders of these private space companies should enjoy legal immunity, the same as is recorded to employees and experts of the Agency.

Therefore, the article proves that gradually ESA should shift from the functions of the direct exploration and use of outer space to the functions of promoting the development of European space public and private law, with focus on planning, supporting private space companies on the basis of competition. All private space companies should have the admission to the Agency launch site on a competitive basis. Orders for space production and services should be distributed through tender procedures. ESA's leading activities should remain arbitrage, but at a much wider scale. These activities should enable ESA to oppose dozens of successful private companies in Europe to several successful companies in the U.S.

In the article, the authors reveal the legal status of the European Space Agency. They identify its imperfect status, due to ignoring by the current legislation the challenges of commercialization in the use of outer space. Therefore, the legal literature on space law does not focus on this problem. In further research, the authors plan to disclose the theoretical aspects of this issue and propose specific amendments and additions to the legislation that establishes the legal status of ESA.

\section{[D] References}

Budget ESA, 2019. https://www.esa.int/About_Us/Welcome_to_ESA/Funding

Convention for the Establishment of a European Space Agency. The text of the Convention was approved by the Conference of Plenipotentiaries, held in Paris on 30 May 1975. The ESA Convention entered into force on 30 October 1980. https://www.riigiteataja. ee/aktilisa/2070/7201/5002/ESA_Convention.pdf

Cosmic Vision. SPACE SCIENCE FOR EUROPE 2015-2025, 2019. http://sci.esa.int/cosmicvision/46510-cosmic-vision/

Encyclopaedia Britannica, 2019. https://www.britannica.com/search?query=social+status

Guiana Space Centre. Rocket Rundown agency.2019. https://rocketrundown.com/home/ launch-sites/guiana-space-centre/

Gannon, Megan. European Space Agency leaders expect a challenging year ahead. 2019. Spacenews. $\quad \mathrm{https}$ ://spacenews.com/european-space-agency-leaders-expect-achallenging-year-ahead/

Halunko, Valentyn and Didenko, Serhii. Private International Space Law. Philosophy and Cosmology, Volume 22, 2019: 16-23. https://doi.org/10.29202/phil-cosm/22/2

Hera's Apex Cubesat will Reveal the Stuff that Asteroids are made of. ESA. 2 May 2019. https://www.esa.int/Our_Activities/Space_Safety/Hera/Hera_s_APEX_CubeSat_will_ reveal_the_stuff_that_asteroids_are_made_of

Hughes, Louise. The Space Industry Act. U.K.K. Space Agency, 2018. http://www.unoosa.org/ documents/pdf/copuos/lsc/2018/tech-01.pdf

Legal status. The Free Dictionary, 2019. https://www.thefreedictionary.com/legal+status 
Smith, Lesley Jane, Ruairidh J.M. Leishman. Up, up and Away: An Update on the U.K.'s Latest Plans for Space Activities. Air and Space Law, 2019. 44. pp. 1-26. https://www. kluwerlawonline.com/abstract.php?area=Journals\&id=AILA2019001

Space for Competitiveness and Growth. Ministerial Council, 2012. https://www.esa.int/ About_Us/Ministerial_Council_2012/Space_for_competitiveness_and_growth2

The Gaia mission. $A \& A$. Volume 595, November 2016. https://doi.org/10.1051/0004$6361 / 201629272$

The space port for Ariane and Vega launch rockets in French Guiana - from Europa into Space. ARTS, 2018. https://arts.eu/blog/the-space-port-for-ariane-and-vega-launchrockets-in-french-guiana-from-europa-into-space

What is ESA? 2019. https://www.esa.int/About_Us/Welcome_to_ESA/What_is_ESA

What is Horizon 2020? 2014. https://ec.europa.eu/programmes/horizon2020/whathorizon-2020 